Weed Science, 48:664. 2000

\title{
Frederick Dana Hess: A Remembrance
}

\author{
When he shall die \\ Take him and cut him out in little stars \\ And he will make the face of $\mathrm{H}$ eaven so fine \\ That all the world will be in love with night \\ And pay no worship to the garish sun \\ Shakespeare, Romeo and Juliet \\ Juliet speaking in Act III, Scene II
}

D an H ess died August 4, 2000. O ne of his last acts was to create an endowment fund for graduate study in applied agriculture at the University of California-D avis, where he obtained his M asters (1973) and Doctoral (1975) degrees in plant physiology. D an was born M arch 22, 1946 in Tacoma, WA and grew up on a farm in central Washington. $\mathrm{He}$ was and will be remembered as a wonderful teacher, an outstanding research scientist, a good administrator, and a fine man. It was not unusual, but it is most worthy of note that among $D$ an's last acts was one designed to benefit students he will never know.

After his selection as the outstanding graduate student by W SSA in 1975, the faculty of Colorado State University's Department of Botany and Plant Pathology was fortunate to recruit and hire D an in 1976 as an assistant professor of weed science. My colleagues and I knew that we had hired a very bright, capable young scientist. We were all disappointed, but not surprised, when he moved to Purdue's Department of Botany and Plant Pathology in 1977. H is research was on modes of action of several important herbicide classes and he taught advanced weed science courses on the physiology and mode of action of herbicides. In 1985, only $10 \mathrm{yr}$ into his career, he was selected as the outstanding research scientist by W SSA.

$\mathrm{D}$ an left Purdue in 1985 to work with the Zoecon Research Institute in Palo Alto, CA as the Director of Plant Science research. After a merger, he became $\mathrm{Director}$ of $\mathrm{Bi}$ ology and Biochemistry research for Sandoz Agro, Inc., a position he held until he was promoted to Vice-President of the N orth American research division of Sandoz in 1995. In 1998, he left Sandoz to begin and lead a new agricultural research unit, AffyAgro within the Affymax Research Institute. The new venture was dedicated to introducing new technology to improve agrochemical research.

Throughout his career, he was first and foremost a weed scientist. He maintained his interest and skill as a teacher by continuing to teach in the annual Purdue University Herbicide Action Intensive Course and was an affiliate fac- ulty member at Purdue and the University of California$D$ avis. $H$ is interest and dedication to weed science was demonstrated by his service and contributions to numerous W SSA committees and was further affirmed by his service as President of the Society in 1998. He was internationally known among weed scientists and was the author of more than 50 scientific articles and book chapters. $\mathrm{H}$ is last article will appear soon in Weed Science.

$D$ an was one of the few truly gifted teachers who could take complex scientific matters and explain them so all could understand. $H$ is gifts as a teacher were the result of hours of hard work and continual preparation, but he made it all-the great teaching, the good writing, and the great research-look so easy. $\mathrm{H}$ is was an example of how to do many things well and we all continue to benefit from his work. $\mathrm{H}$ is contributions to weed science and agriculture are his legacy to us.

$\mathrm{D}$ an is survived by his wife Deborah of Emerald $\mathrm{H}$ ills, CA, three children Tiffany D odge of Palo Alto, CA, Scott $\mathrm{H}$ ess of M iami, FL, and Tonya Weaver of St. Paul, M N , and three grandchildren. $\mathrm{H}$ is mother Slyvia $\mathrm{H}$ ess lives in Woodland, CA and a sister Judy Walden lives in $\mathrm{H}$ onolulu, $\mathrm{HI}$.

The family requests that memorial gifts be contributed to the student endowment fund D an created. Contributions may be sent to:

UC D avis Foundation

F. D an H ess Endowment for Applied Agriculture

$D$ ean's $O$ ffice, College of Agriculture and Environmental Sciences

1 Shields Avenue

University of California-D avis

Davis, CA 95616

Robert L. Zimdahl, Professor, Bioagricultural Sciences and Pest $M$ anagement

Colorado State University, Fort Collins, CO 80523 and Editor, Weed Science rzimdahl@agsci.colostate.edu 